\title{
Ivanna Chaikovska
}

Jagiellonian University in Krakow

e-mail: chaikovska.ivanna.pl@gmail.com, ivanna.chaikovska@doctoral.uj.edu.pl

ORCID: 0000-0002-9425-2852

\section{THE MISMATCH BETWEEN THE MATURITY STRUCTURE OF BANK ASSETS AND LIABILITIES IN POLISH LISTED BANKS AND THE POLISH BANKING SECTOR: AN EMPIRICAL STUDY}

\author{
DOI: $10.15611 /$ pn.2020.9.02 \\ JEL Classification: G21; G28; G32; K22. \\ (C) 2020 Ivanna Chaikovska \\ This work is licensed under the Creative Commons Attribution-ShareAlike 4.0 International \\ License. To view a copy of this license, visit http://creativecommons.org/licenses/by-sa/4.0/ \\ Quote as: Chaikovska, I. (2020). The mismatch between the maturity structure of bank assets \\ and liabilities in Polish listed banks and the Polish banking sector: An empirical study. Prace \\ Naukowe Uniwersytetu Ekonomicznego we Wrocławiu, 64(9).
}

\begin{abstract}
The purpose of the article is to identify the problem of the mismatch between the maturity structure of assets and liabilities of the Polish banking sector and Polish listed banks. The article analyzes the maturity balance sheet structure of the Polish banking sector in 2010 and 2019 and Polish listed banks in 2019. The results of this analysis indicate a significant mismatch in the maturity structure of assets and liabilities of Polish banks and the need for a significant reconstruction of the structure of liabilities in the direction of their extension. Furthermore, the results of the analysis identify the most and the least secure Polish listed banks in terms of mismatches in the maturity balance sheet structure, as well as banks with opposite trends in the maturity structure compared to the Polish banking sector.
\end{abstract}

Keywords: banks, maturity structure of assets and liabilities, Polish listed banks, Polish banking sector, liquidity, balance sheet.

\section{Introduction}

The specificity of banks' activity means that the dominant source of their financing is foreign capital, located in the balance sheet on the liabilities side. Furthermore, most liabilities are usually short-term or payable on demand (e.g. deposits), while assets (e.g. loans) are usually long-term and payable on maturity. Concerning the above, there is a risk of a mismatch between the maturity structure of bank assets 
and liabilities, which may result in the loss of liquidity and a threat to the security of the individual banks and the entire banking sector. Furthermore, the purpose of the article was to identify the problem of the mismatch between the maturity structure of the assets and liabilities of the Polish banking sector and Polish listed banks.

The article analyses the maturity balance sheet structure of the Polish banking sector in 2010 and 2019 and Polish listed banks in 2019. The analysis includes twelve banks listed on the Warsaw Stock Exchange, namely PKO Bank (Powszechna Kasa Oszczędności Bank Polski), Santander Bank, Pekao Bank (Bank Polska Kasa Opieki), mBank, ING Bank, BNP Paribas Bank, Bank Millennium, Alior Bank, Getin Noble Bank, Bank Handlowy w Warszawie, Bank Ochrony Środowiska and Idea Bank. The calculations used the financial data provided by the Orbis Bank Focus database, the National Bank of Poland and the consolidated financial statements of Polish listed banks.

The above analysis will also be the basis for identifying mismatches between the maturity structure of bank assets and the liabilities of the Polish banking sector and Polish listed banks, identifying the most and least secure Polish banks in this context, and identifying banks with reverse trends in the maturity structure compared to the Polish banking sector. To achieve the set purpose, the methods of comparing documents, consolidated financial statements and reports of the National Central Bank were used (especially in the section on the characteristics of the maturity structure of bank assets and liabilities) and methods of descriptive statistics (in the empirical part of the article). In reference to the above, in this paper a research hypothesis was formulated, namely a significant mismatch in the maturity structure of assets and liabilities may leads to a reduction in a bank's safety level by increasing the liquidity risk in the bank.

\section{The maturity structure of bank assets and liabilities: a theoretical approach}

The banking industry, academia and supervisors place a relatively greater emphasis on capital requirements than on liquidity and funding, reflecting the general view that a solvent bank will be liquid (Shi and Liu, 2016). However, the global financial crisis of 2009-2011 confirmed that a lack of liquidity might become one of the first causes of crisis phenomena, and lead to bank insolvency and bankruptcy. In reference to the above, in post-crisis years in order to reduce the liquidity risk the Basel Committee has implemented the minimum liquid requirements for banks.

In accordance with the regulatory framework of Basel III, as a liquidity measure a maturity mismatch could be applied, by using the maturity ladder (contractual periods). The risk of mismatching between the maturity structure of bank assets and liabilities may result in loss of liquidity (Galletta and Mazzù, 2019). As noted in the literature, each asset and each liability contributes to the liquidity position of the bank (Bai, Krishnamurthy, and Weymuller, 2014, p. 3). 
Banks face naturally a liquidity risk relative to their fundamental role in maturity transformation, which means turning illiquid bank assets into short-term liquid bank liabilities (Passmore and Temesvary, 2020). In fact, banks' investment horizon is in general longer than the investment horizon of the banks' creditors. The illiquidity of bank assets coupled with the liquidity promised through bank liabilities leaves banks vulnerable to runs and liquidity crises (Virgilio, 2020, p. 3).

In recent years, market evolution and financial innovation have modified banks' practices and, consequently, the nature of liquidity risk. The main consequence of these various modifications is the increased connection between banking activities and markets. Hence, liquidity has become an important contagion channel for systemic risk. In other words, a loss of the bank's liquidity in a short-term period may lead to its insolvency, followed by bankruptcy or systemic government intervention. This may also contribute to security disruptions at the level of an individual bank or the entire banking sector.

In relation to this, it becomes necessary to constantly monitor the maturity balance sheet structure at the level of individual banks as well as the entire banking sector. The identification of mismatches will allow taking actions aimed at reducing the scale of mismatch between assets and liabilities, in order to avoid a situation in which long-term illiquid assets are financed by short-term unstable sources of financing. At the same time, the need for monitoring and overnighting of maturity mismatch has been acknowledged as a way to reduce rollover risk and preserve financial security and stability (Bologna, 2018, p. 5).

The specificity of banks' activity, namely issuing short-term liabilities (deposits) in exchange for longer-term assets, generate a maturity mismatch between the assets and the liabilities of banks (Ferrero, Nobili, and Sene, 2018, p. 2). In reference to this, it becomes essential to compare assets and liabilities by their maturity dates in order to assess the bank's balance sheet structure and identify its mismatches. The estimation of potential mismatches is based on the method of monitoring the upcoming maturity ladder. For this purpose the components of on-balance and off-balance sheet are broken down by maturity into specific groups (Bai, Krishnamurthy, and Weymuller, 2014, p. 1).

Furthermore, the division into groups depends on the decisions of individual banks and is varied among individual banks. Usually the balance sheet items are divided into the following contractual periods:

- a vista (without a specified date);

- less than 1 month;

- from 1 to 3 months;

- from 3 months to 1 year;

- from 1 to 5 years;

- over 5 years. 
The matching of the abovementioned periods of balance sheet items plays a significant role at the level of an individual bank as well as the entire banking sector. In relation to this, the author analysed the maturity structure of the balance sheets at the level of the entire banking sector in order to identify mismatches, assess the risks associated with them and take actions aimed at changing the balance structure and avoiding crises at macroeconomic level.

\section{Analysis of the maturity structure of assets and liabilities of the Polish banking sector: identification of mismatches}

In order to assess the situation of the Polish banking sector, an analysis was conducted regarding the maturity structure of assets and liabilities of the Polish banking sector. The results of this analysis are presented in Figure 1.

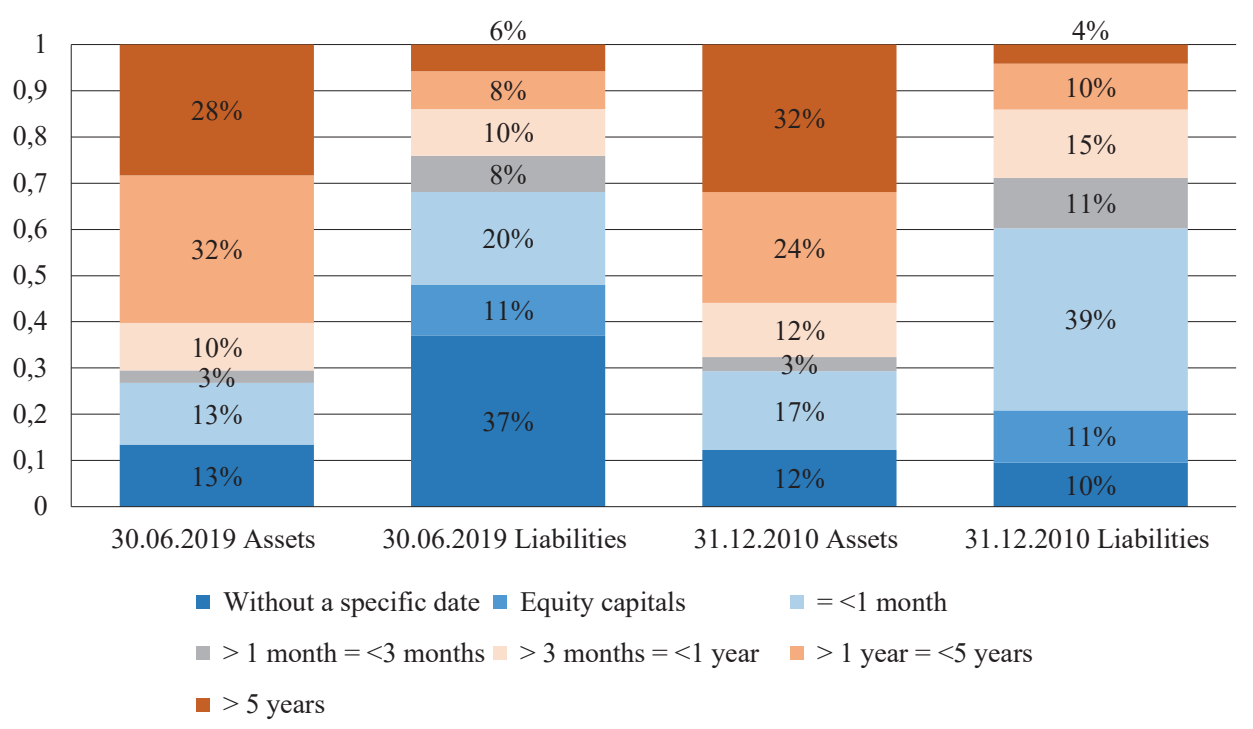

Fig. 1. The maturity structure of assets and liabilities of the Polish banking sector in 2010 and 2019, \% Source: own elaboration based on data from the (National Bank of Poland, n.d.).

The results of the analysis of the maturity balance sheet structure of the Polish banking sector in 2010 and 2019 indicate significant changes occurring in the balance sheet structure of Polish banks. In particular, in 2019 (compared to 31.12.2010) the percentage share of liabilities a vista (without a specified date) increased significantly, namely from $10 \%$ to $37 \%$ (by $27 \%$ ). Increasing the share of liabilities a vista (without a specific date) means an increase in the participation of periodic financial surplus in the Polish sector. In other words, it is a form of transactional money that bank customers can freely use at any time, including mass withdrawal, e.g. due to loss of 
trust in banks, 'bank run'1, crisis phenomena or panic in the banking sector. Changes in the maturity structure of banks by increasing the share of liabilities a vista (without a specific period) can be assessed as adverse changes that lead to an increase in the level of risk associated with the mass withdrawal of funds and loss of liquidity in the entire banking sector. This means that the Polish banking sector in 2019 became more sensitive to potential crisis phenomena compared to 2010 .

Furthermore, Figure 1 shows that significant changes also occurred in the liabilities category within one month, among others, the share of liabilities in this category decreased from 39\% in 2010 to $20 \%$ in 2019 (by 19\%). These changes can be assessed as a positive change, resulting in a decrease in the share of short-term liabilities in bank financing. However, it is important to note that the decrease in the share of liabilities to one month (by 19\%) was mainly due to the increase in the share of liabilities a vista (without a specific period) (by 27\%). In 2019 the percentage share of liabilities in other contract periods remained at a comparably similar level as in 2010 with slight deviations, including the share of liabilities in the range from three months to one year which decreased by $5 \%$ (from $15 \%$ to $10 \%$ ).

In addition, in 2019 one can also note changes in the maturity structure of assets. In particular in 2019, compared to 2010, the share of assets up to one month decreased by $4 \%$ (from $17 \%$ in 2010 to $13 \%$ in 2019), which means a decrease in the share of short-term assets (e.g. loans). At the same time, the percentage share of the asset in a group from one to five years by increased by $8 \%$ (from $24 \%$ to $32 \%$ ), which indicates that the role of long-term assets in the Polish banking sector has been strengthened.

To sum up, the main mismatches between the maturity structure of bank assets and liabilities in 2019 in the Polish banking sector were identified:

- in the category without a specified period - by $24 \%$;

- in the category from 1 to 5 years - by $24 \%$;

- in the category over 5 years - by $22 \%$.

Based on the above, the main mismatches of the maturity structure in 2019 were identified within three categories (namely without a specific date, from one to five years and over five years). Consequently, the following conclusions can be drawn, namely:

- the assets structure of the Polish banking sector exceeded long-term assets, (over 1 year), which represented $60 \%$ of all assets in assets;

- the liabilities structure of the Polish banking sector exceeded short-term liabilities, namely liabilities a vista (without a specific period) and up to 1 month, which represented $57 \%$ of all liabilities. It is also important to note that own

${ }^{1}$ A bank run is a period when many people take their money out of a bank because they are afraid the bank will lose it or go out of business. A banking crisis is a situation characterized by a bank run, bankruptcies of financial institutions or massive government intervention, as well as a widespread imbalance of the stability and security of these institutions (Kaufman, 1999, p. 1). 
funds also played a significant role in the liabilities structure, the percentage share of which in 2019 was $11 \%$.

It is noteworthy that the share of long-term assets in the balance sheet of the Polish banking sector shows an upward trend (by 4\%: from 56\% in 2010 to $60 \%$ in 2019) and remains significant. In turn, the share of short-term liabilities shows an upward trend (by 8\%: from $49 \%$ in 2010 to $57 \%$ in 2019 ).

The above mentioned mismatches of the maturity balance sheet structure testify to the fact that long-term illiquid assets are financed by short-term unstable sources in the Polish banking sector. As a result it has become necessary to take action aimed at reducing the scale of these mismatches at the level of the entire banking sector as well as of individual banks.

\section{Analysis of the maturity structure of assets and liabilities of the Polish listed banks: identification of mismatches}

The analysis of the Polish banking sector balance sheet above identified mismatches between the maturity structure of assets and liabilities of this sector. As at the end of 2019, there were 600 banks in this sector, including 30 commercial banks, 538 cooperative banks and 32 branches of credit institutions. The total assets of the Polish banking sector in 2019 amounted to PLN 2000470 million (Polish Financial Supervision Authority, 2020). Commercial banks, in particular listed banks, played an important role in the Polish sector. On 31st December 2019 the asset value of 12 Polish listed banks was PLN 1503538 million, which corresponded to approximately $75 \%$ of the assets of the entire banking sector (Warsaw Stock Exchange, b.d.).

Taking into account the significant share of listed banks in the Polish sector, it is important to analyse the maturity structure of assets and liabilities at the level of individual banks, in order to identify mismatches at the level of individual banks. In relation to this, the analysis of the maturity structure of assets and liabilities of 12 Polish listed banks is presented in Figure 2.

Figure 2 shows that the maturity balance sheet structure of the analysed listed banks differed significantly. Among those, it is possible to note banks that were characterized by a significant mismatch of their structures, as well as banks with similar maturity structures of balance sheet positions in 2019. Accordingly, all the analysed banks in terms of their maturity structure balance sheet items can be divided into four groups:

- banks with a mismatched structure on a large-scale - Santander Bank, Alior Bank, Getin Noble Bank,

- banks with a mismatched structure on a smaller scale - mBank, BNP Paribas,

- banks with a tailored structure on a smaller scale - Bank Handlowy w Warszawie, Pekao Bank, Millennium Bank,

- banks with a tailored structure on a larger scale - Bank Ochrony Środowiska, Idea Bank. 


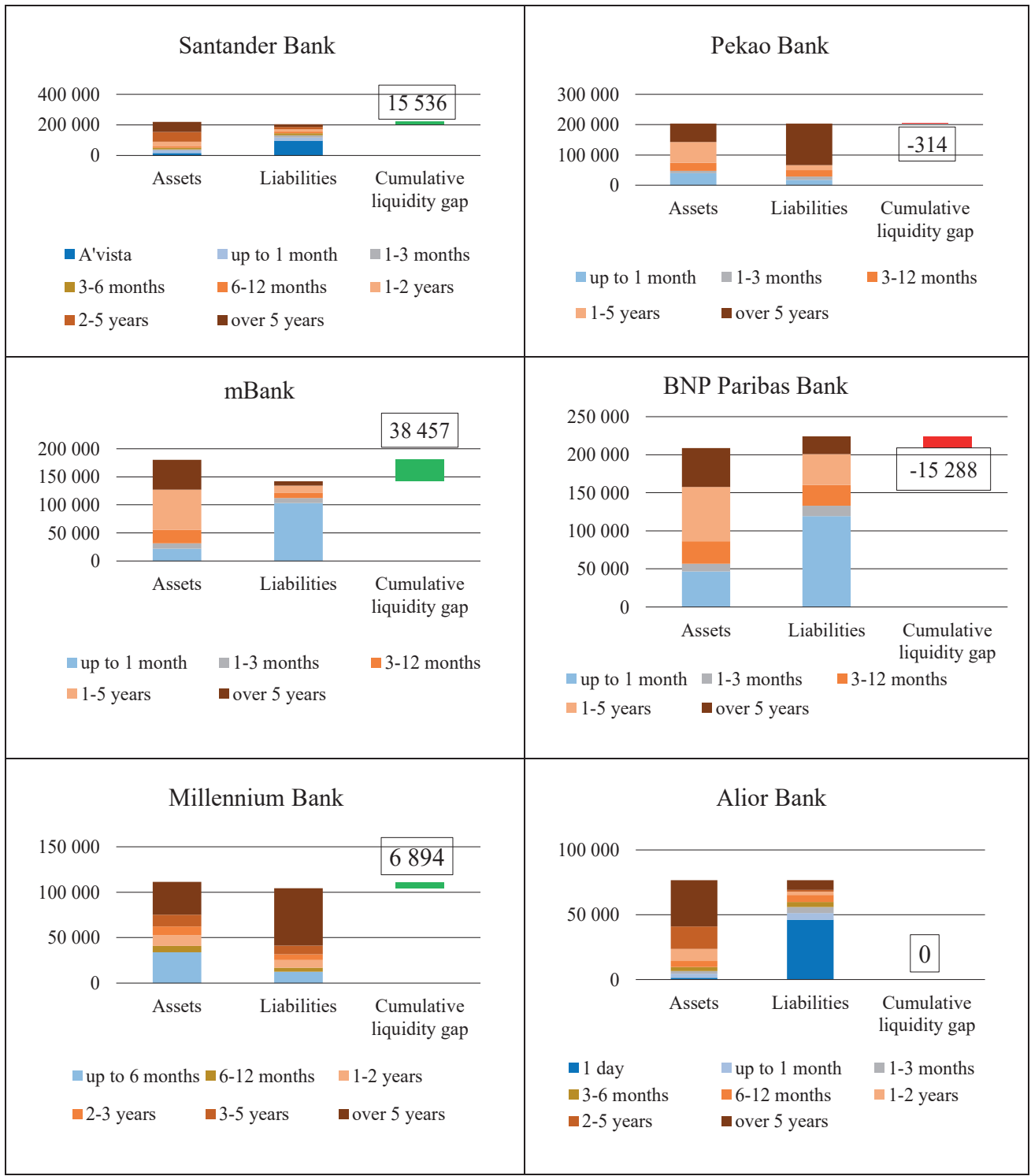




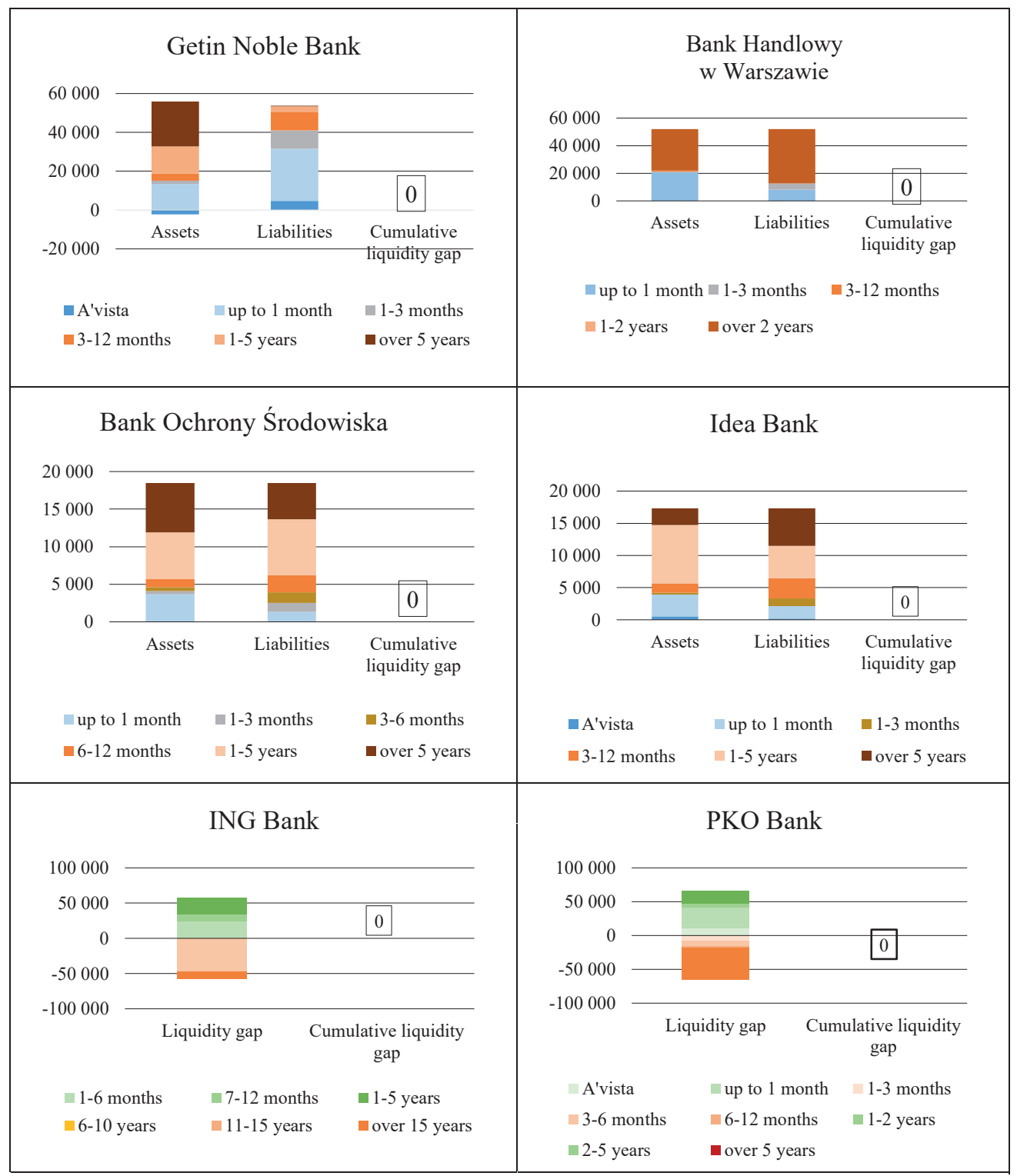

Fig. 2. The maturity structure of assets and liabilities of the Polish listed banks in 2019, PLN million

* In the analysis PKO Bank and ING Bank were presented using a liquidity gap due to the lack of detailed data on the maturity structure of assets and liabilities in the annual consolidated financial statements for 2019.

Source: own elaboration based on the annual consolidated financial statements of the Polish listed banks. 
For a detailed analysis of mismatches at the level of various banks, the maturity balance sheet structure of each of the analysed Polish listed banks is discussed below.

Santander Bank. In 2019, long-term assets over 1 year (72\%) and a vista liabilities $-44 \%$ played a dominant role in Santander Bank. Mismatches were identified in the following categories of assets and liabilities:

- a vista (without a specified period) - by PLN 81229 million or 37\%;

- from 2 to 5 years - by PLN 47573 million or $22 \%$;

- over 5 years - by PLN 49679 million or by $23 \%$.

It is important to note that the mismatches in the balance sheet structure at Santander Bank are similar to the situation in the Polish banking sector.

Pekao Bank. The dominant role belonged to long-term assets $(63 \%)$ and long-term liabilities over 1 year (76\%). Interestingly, in 2019 Bank Pekao noted a high proportion of long-term liabilities, in particular liabilities over 5 years (67\%). Pekao Bank's maturity structure can be assessed as one of the best-matched assets and liabilities due to their maturity. This can also indicate the stable liquidity position of this bank.

mBank. mBank had a high share of long-term assets $70 \%$ (over 1 year) and short-term liabilities $73 \%$ (less than 1 month). The results of the analysis indicate major mismatches in the following categories:

- less than 1 month - by PLN 81338 million or 61\%;

- from 1 to 5 years - by PLN 58077 million or 30\%;

- over 5 years - by PLN 45894 million or $24 \%$.

It is important to note that the mismatches in mBank are similar to the situation in the Polish banking sector.

BNP Paribas Bank. BNP Paribas Bank noted a high share of long-term assets above 1 year (59\%) and short-term liabilities below 1 month (53\%). The visible mismatch in this bank can be seen in the category of assets and liabilities under 1 month, namely PLN 72929 million or 31\%. On the other hand, on a smaller scale, mismatches can be observed in categories from 1 to 5 years (PLN 31007 million or 16\%) and over 1 year (PLN 27642 million or 14\%). It is important to note that in BNP Paribas Bank, slight mismatches can be identified in the maturity structure of balance sheet items. The liquidity position of the bank can be assessed as satisfactory.

Millennium Bank. Millennium Bank was characterized by a high share of long-term assets (63\%) and long-term liabilities (84\%) in 2019. Particular attention should be paid to the fact that over $61 \%$ of Millennium Bank's liabilities were for over 5 years, which proves the high stability of the deposit base. This also shows the bank has a strong position in terms of liquidity.

Alior Bank. In Alior Bank, as in the Polish banking sector, long-term assets $(81 \%)$ and short-term liabilities (67\%) played a dominant role. In this bank, significant mismatches were identified in the category of assets and liabilities up to 1 month PLN 46757 million or $61 \%$ (including up to 1 day 58\%) and in the category over 1 year PLN 50780 million or 66\%. It is important to note that Alior Bank may 
have a high level of liquidity risk due to significant mismatches in the structure of maturity balance sheet items, mainly by financing long-term illiquid assets $(47 \%$ over 5 years) by short-term unstable financing sources (60\% 1-day). Alior Bank's maturity structure can be assessed as one of the most unmatched assets and liabilities due in terms of maturity, which may also indicate that the bank's liquidity position is unstable.

Getin Noble Bank. In 2019, Getin Noble Bank had a dominant role in longterm assets (69\%) and short-term liabilities, less than 1 month (59\%). Significant mismatches were noted in all contract periods, in particular in the category up to 1 month by PLN 1347836 million or 25\% and in categories over 5 years by PLN 2280884 million or $42 \%$. Furthermore $43 \%$ of assets over 5 years were financed through $50 \%$ of liabilities up to 1 month. This reflects the situation in which long-term assets are financed with short-term liabilities. which may lead to liquidity losses due to mismatches in the maturity structure of assets and liabilities.

Bank Handlowy w Warszawie. At Bank Handlowy w Warszawie 58\% of long-term assets corresponded to $76 \%$ of long-term liabilities (over 1 year). In turn, in the short-term perspective (up to 1 month) assets from liabilities differed by PLN 1259 092 million which corresponds to 24\%. Despite this, the maturity structure of Bank Handlowy w Warszawie can be assessed as sufficiently suited to both the assets and liabilities. In addition, the bank's balance sheet structure reflects the situation in which long-term assets are covered by long-term liabilities, which contributes to strengthening its position in liquidity.

Bank Ochrony Środowiska. The maturity structure of the balance sheet items of Bank Ochrony Środowiska was best matched in terms of dates. The confirmation of this statement is the high share of both long-term assets (69\%) and long-term liabilities $(67 \%)$. This means that this bank has a well-matched maturity structure of assets and liabilities and is protected against loss of liquidity despite slight mismatches (e.g. in the category up to 1 month PLN 2324 million or 13\%).

Idea Bank. In 2019, long-term assets (67\%) and long-term liabilities (63\%) played a dominant role. Mismatches on a smaller scale were recorded in the category up to 1 month in the amount of PLN 1448 million or 8\%. It is important to note that the term structure of Idea Bank's assets and liabilities should be assessed as sufficiently adapted.

In the analysis there were also included ING Bank and PKO Bank. In these banks, the maturity structure of assets and liabilities was not graphically presented due to the lack of detailed data on this subject in the consolidated annual reports. However, the mismatches in the balance sheet structure of these banks were represented by the liquidity gap defined as a mismatch between assets and liabilities across the term structure. Thus, the liquidity gap can occur either when there is a surplus of assets over liabilities or a surplus of liabilities over assets, and it is often defined for different maturity buckets along with the term structure (The Banking Sector Under Financial Stability, 2018, p. 82). 
ING Bank. The main mismatches in the ING Bank maturity structure were recorded in the category from 1 to 6 months in the amount of PLN 24322 million and in the category from 11 to 15 years in the amount of PLN 45973 million.

PKO Bank. At PKO Bank, mismatches were identified in the category over 5 years in the amount of PLN 115025 million (Figure 2).

The results of the analysis of the maturity structure of assets and liabilities of Polish listed banks indicate a group of banks in which one can see a similar trend of mismatches as in the Polish banking sector, namely in Santander Bank, mBank, BNP Paribas Bank, Alior Bank, and Getin Noble Bank. There was also identified the second group of Polish listed banks, in which one can notice a reverse tendency in the balance sheet structure than in the Polish banking sector, namely Pekao Bank, Millennium Bank, Bank Handlowy w Warszawie, Bank Ochrony Środowiska and Idea Bank.

\section{Conclusion}

The results of the empirical study show that in 2019, the most secure in terms of matching the maturity structure of assets and liabilities, was Bank Ochrony Środowiska, in which the share of long-term assets was $69 \%$, and long-term liabilities $-67 \%$ (mismatch by $2 \%$ ). The least secure in terms of matching the term structure of balance sheet items was Alior Bank, in which the share of long-term assets was $81 \%$ and long-term liabilities $-15 \%$ (mismatch by $66 \%$ ). Furthermore, among the analyzed banks, in 2019 Alior Bank was characterized by the highest level of assets and liabilities mismatch, and as a consequence, a significant risk of liquidity loss. This paper also shows that the analysed banks' maturity mismatch of assets and liabilities can lead to serious risks (e.g. mismatch by $66 \%$ in Alior Bank in $2019^{2}$ ). The results of the empirical study prove the formulated research hypothesis that significant mismatches in the maturity structure of assets and liabilities lead to a reduction in the bank's safety level by increasing the liquidity risk in the bank.

Observing the bank's financial statements, in most of the analysed banks the cumulative liquidity gap are mostly highly positive, which means the strong coping capacity of liquidity risk (Figure 2). Instead, some banks such as Pekao Bank and BNP Paribas Bank, showed negative cumulative liquidity gaps are and face serious liquidity risk, while their maturity mismatch degree is low. Therefore, these banks must implement strict liquidity risk management, formulate appropriate liquidity

${ }^{2}$ In the first half of 2020, Alior Bank realized a net loss of PLN -513.4 million, mainly due to the pandemic COVID-19 and a decrease in net interest income because of interest rate cuts by the National Bank of Poland (NBP). The Bank's liquidity position in the first half of 2020 remained at a safe level, namely the LCR ratio was $148 \%$ on $31 / 12 / 2019$ and increased to $187 \%$ on $30 / 06 / 2020$. Half-Yearly Financial Statements of Alior Bank as at 30 June 2020, https://www.aliorbank.pl/dodatkowe-informacje/ relacje-inwestorskie/wyniki-finansowe.html, p. 9. 
risk regulation and prevention strategy according to the requirement of the relevant indicators, namely LCR and NSFR.

In addition to the liquidity risk, the mismatch between the maturity of assets and liabilities also exposes banks to interest rate risk, namely unexpected changes in interest rates impact on banks' performance (Baradwaj, Dewally, Flaherty, and Shao, 2020). When interest rates are volatile and hard to predict, banks must manage interest rate risk effectively to protect liquidity, capital and prevent insolvency. In particular, this is an important and necessary task to be implemented at a time of zero interest rates policy during the COVID-19 pandemic ${ }^{3}$. On the one hand, low interest rates are beneficial for an economy facing a deep and prolonged recession (e.g. during the current pandemic) as they reduce funding costs, ease credit conditions and expand financial wealth by increasing asset prices, however they also negatively influence bank security due to pressures on banks' profitability and risk-taking incentives (Ferrero, Nobili, and Sene, 2018, p. 2).

The mismatch in the maturity structure of assets and liabilities may become one of the main reasons for losing liquidity at the level of a particular bank, and of the entire banking sector. In relation to this, it becomes necessary to significantly restructure the structure of liabilities towards their extension in order to adjust the maturity dates of liabilities and the maturity of assets. In other words, banks must strengthen the management of maturity structure, namely optimize the term structure of assets and liabilities, adjust the proportion of current deposit, mid-term and long-term loan, strengthen the monitoring of loan quality, and control the non-performing loan ratio. Moreover, it is important to strengthen the supervision on liquidity risk of maturity mismatch.

\section{References}

Bai, J., Krishnamurthy, A., and Weymuller, C. (2014). Measuring liquidity mismatch in the banking sector. Bank for International Settlements. Retrieved from https://www.bis.org/events/conf140909/ bai_krishnamurthy_weymuller_paper.pdf

Baradwaj, B., Dewally, M., Flaherty, S., and Shao Y. (2020). The management of interest rate risk: Are Maryland banks different? Baltimore business review. A Maryland Journal.

Bologna, P. (2018). Banks'Maturity Transformation: Risk, Reward, and Policy ( IMF Working Papers, $\mathrm{WP} / 18 / 45)$.

Ferrero, G., Nobili, A., and Sene, G. (2018). Credit risk taking and maturity mismatch: The role of the yield curve. Retrieved from https:/www.ecb.europa.eu/pub/conferences/shared/pdf/ 20180906_2nd_annual_ws/Ferrero_Nobili_Sene_paper.pdf

3 For instance, in Poland in the first half of 2020, the National Bank of Poland cut three times the interest rates, namely on March 14, 2020, on April 8, 2020 and on May 28, 2020 (National Bank of Poland, Monetary policy, https://www.nbp.pl/home.aspx?f=/polityka_pieniezna/dokumenty/komunikaty_rpp.html). 
Ivanna Chaikovska

Galletta, S., and Mazzù, S. (2019). Liquidity risk drivers and bank business models. Risks Journal, (7). Indranarain Ramlall. (2018). The banking sector under financial stability. Retrieved from https:// books.google.pl/books?id=9x59DwAAQBAJ\&pg=PA80\&lpg=PA80\&dq=Mismatch + of + the + term + structure + of + assets + and + liabilities $+i n+$ bank \& source $=$ bl\&ots $=c 1$ hwsoyojp $\&$ sig $=$ ACfU3U1WBmH3AmfwTLsBN7RS31rZ0ufyeA\&hl=pl\&sa=X\&ved=2ahUKEwj68 7Dv6zqAh XpiIsKHSq9AroQ6AEwEno-ECAwQAQ\#v=onepage\&q=Mismatch $\% 20 \mathrm{of} \% 20$ the $\% 20$ term $\% 20$ structure $\% 20$ of $\% 20$ assets\%20and\%20liabilities\%20in\%20bank\&f=false

Kaufman, G. (1999). Banking and currency crisis: A taxonomy and review (Loyola University of Chicago Working Paper).

National Bank of Poland. (n.d.). Financial System Stability Reports. Retrieved from https://www.nbp. $\mathrm{pl} /$ home.aspx?f=/systemfinansowy/stabilnosc.html

Passmore, W., and Temesvary, J. (2020). Investor demands for safety, bank capital, and liquidity measurement. Finance and Economics Discussion Series, Federal Reserve Board. Retrieved from https://www.federalreserve.gov/econres/feds/files/2020079pap.pdf

Polish Financial Supervision Authority. (2020). Monthly data for the banking sector-April 2020. Retrieved from https://www.knf.gov.pl/?articleId $=56224 \& p$ id $=18$

Shi, B., and Liu, H. (2016). Study on the liquidity risk of deposit and loan maturity mismatch in commercial banks. Advances in Economics, Business and Management Research, 16.

Virgilio, D. (2020). The transmission of bank liquidity regulation in Slovenia and macroprudential policy implications (The Bank of Slovenia Working Papers, nr 8/2020). Retrieved from https:// bankaslovenije.blob.core.windows.net/publication-files/wp_8_20.pdf

Warsaw Stock Exchange. (b.d.). List of banks listed on the Warsaw Stock Exchange. Retrieved from https://www.gpw.pl/spolki

\section{NIEDOPASOWANIE STRUKTURY TERMINOWEJ AKTYWÓW I PASYWÓW W POLSKICH BANKACH GIEŁDOWYCH ORAZ POLSKIM SEKTORZE BANKOWYM: ANALIZA EMPIRYCZNA}

Streszczenie: Celem artykułu jest identyfikacja problemu niedopasowania terminowej struktury zapadalności aktywów i wymagalności pasywów polskiego sektora bankowego oraz polskich banków giełdowych. Przeanalizowano terminową strukturę bilansową polskiego sektora bankowego w latach 2010 i 2019, jak również polskich banków giełdowych w 2019 roku. Wyniki tej analizy wskazują na znaczne niedopasowanie w strukturze terminowej aktywów i pasywów polskich banków oraz na konieczność istotnej przebudowy struktury pasywów w kierunku ich wydłużenia. Ponadto zostały zidentyfikowane najbardziej i najmniej bezpieczne polskie banki giełdowe pod względem niedopasowania terminowej struktury bilansowej. Opisano również banki, w których zachodzą odwrotne tendencje w strukturze terminowej w porównaniu ze strukturą polskiego sektora bankowego.

Słowa kluczowe: bank, terminowa struktura zapadalności aktywów i wymagalności pasywów, polskie banki giełdowe, polski sektor bankowy, płynność, bilans. 